\title{
Australian Journal of

\section{Impacts of vermicomposting rates on growth, yield and qualities of red seedless watermelon}

\author{
Tahir Lawan Dalorima ${ }^{1}$, Abd Jamil Zakaria ${ }^{1}$, Ali Majrashi ${ }^{2}$, Khairil Mahmud ${ }^{1}$, Khamsah Suryati Mohd ${ }^{1}$, \\ Hasbullah Muhammad ${ }^{1}$, Mohammad Moneruzzaman Khandaker*1
}

\author{
${ }^{1}$ School of Agriculture Science \& Biotechnology, Faculty of Bioresources and Food Industry, Universiti Sultan Zainal \\ Abidin, Besut Campus, 22200 Besut, Terengganu, Malaysia \\ ${ }^{2}$ Department of Biological Science, Faculty of Science, Taif University, Taif, Saudi Arabia
}

*Corresponding author: moneruzzaman@unisza.edu.my

\begin{abstract}
A study was conducted at the teaching and research farm of the Faculty of Bioresources and Food Industry at Universiti Sultan Zainal Abidin (UniSZA) with an objective of determining the best rates for vermicompost application on red seedless watermelon var. Crimson sweet. In this research, watermelon crimson red flesh seedless variety was used as planting materials and different application rates of vermicompost were the major factor of the experiment. The research was a potted layout experiment in a completely randomized design (CRD). Sixteen (16) pots were randomly arranged in a nursery and $10 \mathrm{~kg}$ of BRIS soil was added in to each pot until $10 \mathrm{~cm}$ of soil furrow slice was achieved. Application of vermicompost at the rates of 5, 10, 15, 20 tha ${ }^{-1}$ and untreated control were applied, with four replications each, single plant was taken as an experimental unit from each replicate. Vermicompost treatment at the rate of $15 \mathrm{t} \mathrm{ha}^{-1}$ increased stomatal conductance, transpiration rate and the least days required to $50 \%$ flowering was significantly different compared with other treatments and control. The vermicompost application at the rate of $20 \mathrm{t} \mathrm{ha}^{-1}$ positively influences leaf area, net photosynthetic rate, internal carbon dioxide, number of flowers and fruits weight of watermelon. This findings also revealed that quality properties of watermelon like rind thickeness, TSS, $\mathrm{pH}$, anthocyanin, juice and ash contents were improved with the application rate of $20 \mathrm{t} \mathrm{ha}^{-1}$. Vermicompost application rate of $15-20 \mathrm{t} \mathrm{ha}^{-1}$ is recommended for watermelon production.
\end{abstract}

Keywords: watermelon, vermicompost, rates, growth, yield, qualities.

Abbreviations: CRD_completely randomized design, BRIS_beach ridges interspersed with swales, $\mathrm{t} \mathrm{ha}^{-1}$ _ton per hectare, DAT_days after transplant, C: N_carbihydrates: nitrogen, VC_vermicompost, Pn_net photosynthetic rate, TSS_total soluble solids, SE_standard error, $Q A$ Aquantification of anthocyanin, $\mu \mathrm{M} \_$micro mole, Ta_air temperature, ANOVA_analysis of variance

\section{Introduction}

Watermelon plant is a native of Southern Sahara of Africa, it belongs to the family cucurbitacea and botanically identified as Citrulus lanatus. Watermelon adapts well to a wide range of climatic conditions, it now cultivated in all the tropics and subtropical countries of the world with China been its largest producer (Adeoye et al., 2007). Watermelon mostly contains water $(93.2 \%)$ and other nutrients such as sugar and many vitamins such as thiamin, riboflavin, and niacin. Macronutrient potassium is also available in watermelon fruits, which is considered to help in the control of high blood pressure and perhaps avert strokes (IITA, 2013). It has been also reported that potassium helps in reducing high blood pressure and protect formation of stone in kidney.

The third world's better means of achieving soil fertility improvement and better crop production is from the use of organic fertilizer, been it inexpensive and readily accessible to the dwellers, of which animal dropping is largely available (Odedina et al., 2011). The use of organic fertilizers has enlightened farmers from the use and total reliance on synthetic fertilizers on soil fertility improvement (Schelge, 2000). Vermicompost are formed with the activities by epigeic earthworms, such as Red Wigglers (Eisenia fetida) to decompose farm, food and animal wastes. The resulting compost is high in available nitrogen and has C:N ratios of about 15:1 rendering organic matter more mineralizable than thermophilic compost by pretreating organic wastes at temperatures between $43-63^{\circ} \mathrm{C}$, organic standards of pathogens and weed seeds suppression can be met. Like thermophilic compost, vermicompost has high organic matter, water holding capacity and nutrient retention but it differs in that it has faster mineralization rates, and thus greater nutrient supply rates owning to its lower C:N ratio. Apart from the nutrients in organic, its effects on the enhancement of soil organic content, soil texture and the biological life of the soil are well documented particularly at high rates of application in on field trials. Some evidence suggested that it may contain other growth-promoting substances like natural hormones and B vitamins (Leonard, 2006). The incorporation of vermicompost increased soil organic matter and total nitrogen improved the efficiency of soil phosphorus, soil organisms population increment, especially bacterias, and 
activity increase of soil enzymes like urease. Boyhan, (2000) reported that organic manures increased soil organic matter content and thus total nitrogen. In trying to make the world green and free of inorganic sources of plant nutrients, the available nutrients of organic source has to be renewed for proper soil fertility management (King, 1990). There are many research studies carried out that indicate the benefits derived by vermicompost which improves the performance of plants (Jeffries, 1987), is known to improve phosphorus nutrition by accessing large surface area of soil (Stancheva et al., 2004), improvement of soil acidity (Li et al., 1991) and making phosphate available to plants (Tarafdar and Marschner, 1994). The watermelon has no exception from other plants, it requires nutrients and an idle soil condition to thrive best. Inorganic fertilizers are expensive and problematic when applied in excess than organic fertilizers and hence the need for more sources of organic fertilizers and application rates of organic fertilizers is paramount to investigation for proper soil-plant utilization and farm inputs economy. Thus, the objective of this research was to identify the best application rate of vermicompost on red seedless watermelon.

\section{Results}

Vine length and leaf area of watermelonDifferent rates of vermicompost applied to watermelon at fourteen (14) days after transplant showed that rates of 5, 10, $15 \mathrm{t}$ ha-1 with vine length values of $12.45,12.54$ and $11.20 \mathrm{~cm}$ respectively are significantly different with the control which has the least value of $9.41 \mathrm{~cm}$ (Fig. 1). At forty-five (45) days after transplant 5 and $10 \mathrm{t}$ ha-1 produces the longest vine length $(270$ and $260 \mathrm{~cm})$ which is statistically different with control $(64 \mathrm{~cm}), 15 \mathrm{t} \mathrm{ha}-1$ and $20 \mathrm{t}$ ha-1 are statistically different from each other but different with the least control and other treatments. Application rates at 5, 10, 15 and $20 \mathrm{t}$ ha1 with values of $436.25 \mathrm{~cm}, 437.5 \mathrm{~cm}, 392 \mathrm{~cm}$ and $409.5 \mathrm{~cm}$ at 65 days after transplant are significantly different with the control with the lest mean value of $192.5 \mathrm{~cm}$ (Fig. 1).

The results showed that vermicompost application rates significantly affect the leaf area of watermelon crops (Fig. 2). Leaf area at fourteen days after transplant was the highest at $20 \mathrm{t}$ ha- 1 with a value of $20.5 \mathrm{~cm} 2$, and it is significantly different with 5, 10 and $15 \mathrm{t}$ ha- 1 with mean values of 24,25 , $26 \mathrm{~cm} 2$. The control at 14 DAT had the lowest leaf area $(20.5 \mathrm{~cm} 2)$ and it is statistically different with the other treated watermelon plants. No significant difference was observed amongst treated plants at 45 DAT but there are significantly different with the control (Fig 2). Leaf area at 75 DAT was the least in the control with the value of $52.25 \mathrm{~cm} 2$ and it significantly differs with 5, 10, 15 and 20 t ha- 1 at 82 , 86,87 and $89 \mathrm{~cm} 2$, respectively.

\section{Net photosynthetic rate}

Net photosynthetic rate measured at 14 DAT recorded $20 \mathrm{t}$ ha- 1 of vermicompost to be of the highest mean value $(10.05 \mu \mathrm{m} / \mathrm{m} 2 / \mathrm{s})$, the control, 5, and $10 \mathrm{t}$ ha- 1 are significantly different from application rate of $20 \mathrm{t}$ ha-1 (Fig. $3 \mathrm{~A})$. However, $15 \mathrm{t}$ ha- $1(9.41 \mu \mathrm{m} / \mathrm{m} 2 / \mathrm{s})$ is not statistically different from $20 \mathrm{t}$ ha- 1 . Means recorded at 45 DAT indicated that at application rate at 10,15 and $20 \mathrm{t}$ ha- 1 does not differ statistically ( $p \leq 0.05$ ). However, the control
(19.95 $\mu \mathrm{m} / \mathrm{m} 2 / \mathrm{s})$ had significant difference with all the application rates. At 75 DAT, 20 t ha-1 had the highest mean value $(24.35 \mu \mathrm{m} / \mathrm{m} 2 / \mathrm{s})$ amongst the treatment, moreso it differs statistically with the least control treatment (19.53 $\mu \mathrm{m} / \mathrm{m} 2 / \mathrm{s}$ ) (Fig. 3A).

\section{Internal carbondioxide}

Data recorded at 14 DAT shows that application rate of 15 and $20 \mathrm{tha}-1$ of vermicompost had the highest internal $\mathrm{CO} 2$ values of 5.24 and $5.1 \mu \mathrm{m} / \mathrm{mol}$ respectively and does not vary statistically (Fig. 3B). The control with the least internal CO2 $(2.54 \mu \mathrm{m} / \mathrm{mol})$ varies significantly with all the treatments. Similarly, at 45 DAT 15 and 20 t ha- 1 are the highest treatments with mean values of 11.88 and 12.31 $\mu \mathrm{m} / \mathrm{mol}$ respectively as compared with the control with the least internal $\mathrm{CO} 2$ value $(6.2 \mu \mathrm{m} / \mathrm{mol})$. At $75 \mathrm{DAT}$, plant treated with $20 \mathrm{t}$ ha-1 produced the highest internal $\mathrm{CO} 2$ concentration $(8.13 \mu \mathrm{m} / \mathrm{mol})$, whereas control produced the lowest internal $\mathrm{CO} 2$ concentration $(5.78 \mu \mathrm{m} / \mathrm{mol})$ and their difference was statistically significant (Fig. 3B).

\section{Stomatal conductance}

Data recorded for stomatal conductance reveals that, application rates of vermicompost at 14 DAT shows a significant difference between the control $(0.03 \mathrm{mmol} / \mathrm{m} 2 / \mathrm{s})$ and $10 \mathrm{t}$ ha-1 application rate with the higher value of stomatal conductance $(0.04 \mathrm{mmol} / \mathrm{m} 2 / \mathrm{s})$ (Fig. 3C). However, at 45 DAT 10, 15 and $20 \mathrm{t}$ ha-1 with stomatal conductance values of 17,19 and $16 \mathrm{mmol} / \mathrm{m} 2 / \mathrm{s}$, respectively does not differ significantly between each other, but varies significantly with the control with the lowest stomatal conductance value $(0.04 \mathrm{mmol} / \mathrm{m} 2 / \mathrm{s})$ at $p \leq 0.05$ (Fig. $3 \mathrm{C})$. At 75 DAT, no significant differences were recorded amongst the treatment at $p \leq 0.05$.

\section{Transpiration rate}

Transpiration rate at 14 DAT showed no significant differences between application rate of 10,15 and $20 \mathrm{t}$ ha-1 (1.85, 1.9 and $1.84 \mathrm{mmol} / \mathrm{m} 2 / \mathrm{s}$, respectively) (Fig. 3D). The control and $5 \mathrm{t}$ ha-1 does not differ significantly, however they are statistically different from the former. At 45 DAT, 15 and $20 \mathrm{t}$ ha- 1 had the highest rate transpiration rate and does not differ statistically moreso, they differ significantly from the control which has the least mean value (1.55 $\mathrm{mmol} / \mathrm{m} 2 / \mathrm{s}$ ). Data recorded at 75 DAT has no significant difference amongst the treatment and transpiration rate decreases with harvesting stage (Fig. 3D).

\section{Days to $50 \%$ flowering and number of flowers}

The Table below shows recorded number of flowers according to watermelon flower's sex. Data for male flower indicates that $20 \mathrm{t}$ ha-1 had the highest mean value (35), followed by $15 \mathrm{t}$ ha-1 (33) which do not vary statistically at $\mathrm{p}$ $\leq 0.05$ (Table 2). However, the control with the least value (13) has significant difference with all the treatments. Similarly, 20 tha-1 produces the highest female flower mean value (20) and is significantly different with all the treatments including the control which denotes the least female flower number (8) (Table 2). From the results, it was 
Table 1. Physiochemical properties of vermicompost used in the experiment.

\begin{tabular}{lc}
\hline Parameters of vermicompost & Content \\
\hline $\mathrm{pH}$ & $7.83 \pm 0.05$ \\
Total C $(\mathrm{g} / \mathrm{kg})$ & $285.6 \pm 1.77$ \\
Total $\mathrm{N}(\mathrm{g} / \mathrm{kg})$ & $24.20 \pm 1.0$ \\
Available $\mathrm{P}(\mathrm{g} / \mathrm{kg})$ & $9.82 \pm 0.11$ \\
Organic matter $(\mathrm{g} / \mathrm{kg})$ & $494.4 \pm 2.6$ \\
Exchangeable $\mathrm{C} / \mathrm{N} \mathrm{ratio}$ & $12.2 \pm 0.12$ \\
Exchangeable $\mathrm{K}(\mathrm{g} / \mathrm{kg})$ & $14.6 \pm 0.16$ \\
Exchangeable $\mathrm{Ca}(\mathrm{g} / \mathrm{kg})$ & $22.4 \pm 2.88$ \\
Exchangeable $\mathrm{Mg}(\mathrm{g} / \mathrm{kg})$ & $5.96 \pm 0.10$ \\
Exchangeable $\mathrm{Na}(\mathrm{g} / \mathrm{kg})$ & $6.22 \pm 0.03$ \\
Exchangeable $\mathrm{Cu}(\mathrm{g} / \mathrm{kg})$ & $0.92 \pm 0.03$ \\
Exchangeable $\mathrm{Fe}(\mathrm{g} / \mathrm{kg})$ & $7.92 \pm 0.13$ \\
Exchangeable $\mathrm{Mn}(\mathrm{g} / \mathrm{kg})$ & $12.86 \pm 0.15$ \\
Exchangeable $\mathrm{Zn}(\mathrm{g} / \mathrm{kg})$ & $13.7 \pm 0.13$ \\
\hline All the data are mean of three replication.
\end{tabular}

All the data are mean of three replication.

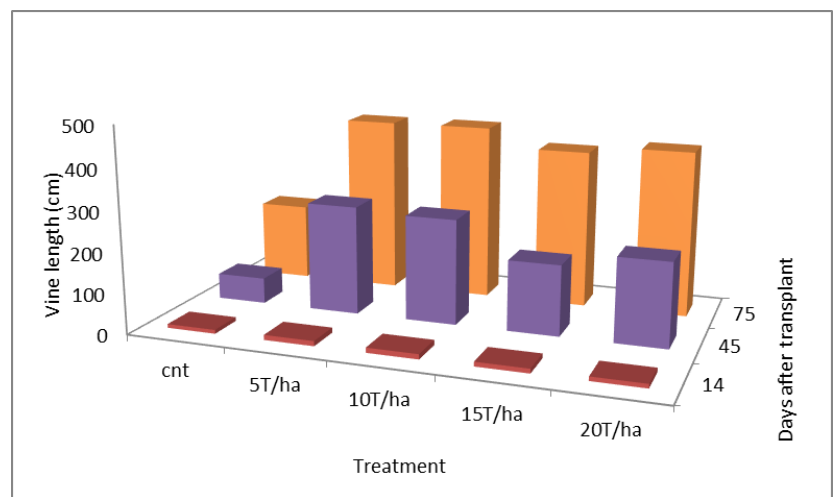

Fig 1. Effects of vermicompost application rates on the vine length watermelon. Bars indicate $\pm S E$ and different letters represent the statistical significance at $p<0.05$.

Table 2. Effects of vermicomposting rates on the flowers and fruit production of watermelon.

\begin{tabular}{|c|c|c|c|c|}
\hline \multirow[t]{2}{*}{ Treatment } & \multicolumn{2}{|c|}{$\begin{array}{l}\text { Parameters } \\
\text { Flowers production }\end{array}$} & \multirow[t]{2}{*}{ Days to $50 \%$ flowering } & \multirow[t]{2}{*}{ Fruits weight ( $\mathrm{t} \mathrm{ha}{ }^{-1}$} \\
\hline & Male & Female & & \\
\hline Control & $12.83 \mathrm{~d}$ & $5.38 \mathrm{e}$ & $51.23 \mathrm{a}$ & $1200.06 \mathrm{~d}$ \\
\hline 5 t ha $^{-1}$ & $21.5 c$ & $8.50 \mathrm{~d}$ & $42.21 \mathrm{~b}$ & 2016.67 c \\
\hline $10 \mathrm{tha}^{-1}$ & $26.03 \mathrm{~b}$ & $11.67 \mathrm{c}$ & $41.37 \mathrm{~b}$ & $2191.67 \mathrm{~b}$ \\
\hline 15 tha $^{-1}$ & $32.8 \mathrm{a}$ & $16.5 b$ & $40.43 \mathrm{~b}$ & $2566.68 \mathrm{a}$ \\
\hline $20 \mathrm{tha}^{-1}$ & $35.25 \mathrm{a}$ & $19.5 \mathrm{a}$ & $48.15 \mathrm{a}$ & $2650.50 a$ \\
\hline LSD & 3.58 & 2.4 & 3.16 & 162.43 \\
\hline CV & 6.38 & 9.08 & 3.24 & 3.5 \\
\hline
\end{tabular}

Mean values with the same letters within the same column are not significantly different at $p \leq 0.05$.

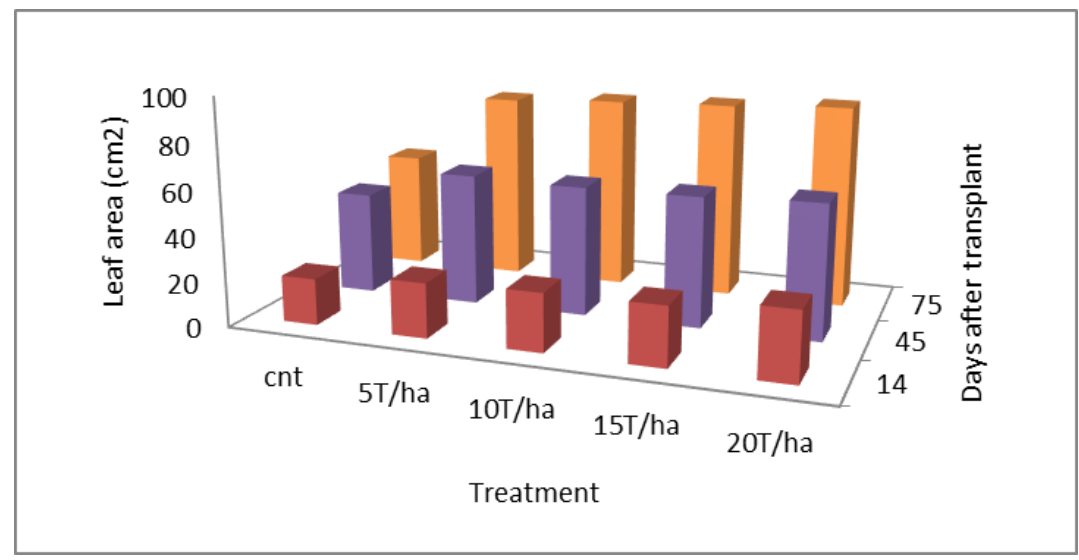

Fig 2. Effects of vermicompost application rates on the leaf area. Bars indicate \pm SE and different letters represent the statistical significance at $p<0.05$. 
Table 3. Effects of vermicomposting rates on quality of fruits of red seedless watermelon.

\begin{tabular}{lcccccc}
\hline Treatment & Rind $(\mathrm{cm})$ & TSS ( $\left.{ }^{\circ} \mathrm{BRIX}\right)$ & Ash Cnt $(\%)$ & Juice Cnt (\%) & $\mathrm{pH}$ & Anthocynin \\
\hline $0 \mathrm{t} \mathrm{ha}^{-1}$ & $1.55 \mathrm{a}$ & $7.95 \mathrm{~b}$ & $8.65 \mathrm{a}$ & $91.13 \mathrm{c}$ & $5.26 \mathrm{~b}$ & $0.13 \mathrm{c}$ \\
$5 \mathrm{t} \mathrm{ha}^{-1}$ & $1.43 \mathrm{ab}$ & $8.33 \mathrm{~b}$ & $8.03 \mathrm{ab}$ & $93.65 \mathrm{~b}$ & $5.64 \mathrm{a}$ & $0.13 \mathrm{c}$ \\
$10 \mathrm{t} \mathrm{ha}^{-1}$ & $1.35 \mathrm{bc}$ & $8.10 \mathrm{~b}$ & $7.90 \mathrm{~b}$ & $94.08 \mathrm{ab}$ & $5.35 \mathrm{ab}$ & $0.16 \mathrm{~b}$ \\
$15 \mathrm{t} \mathrm{ha}^{-1}$ & $1.18 \mathrm{~cd}$ & $10.23 \mathrm{a}$ & $7.93 \mathrm{~b}$ & $94.55 \mathrm{ab}$ & $5.58 \mathrm{ab}$ & $0.18 \mathrm{ab}$ \\
$20 \mathrm{t} \mathrm{ha}^{-1}$ & $1.13 \mathrm{~d}$ & $11.13 \mathrm{a}$ & $6.93 \mathrm{c}$ & $95.90 \mathrm{a}$ & $5.66 \mathrm{a}$ & $0.20 \mathrm{a}$ \\
$\mathrm{LSD}$ & 0.18 & 1.44 & 0.65 & 1.90 & 0.36 & 0.025 \\
$\mathrm{CV}$ & 6.09 & 3.77 & 3.77 & 0.93 & 3.07 & 7.17 \\
\hline
\end{tabular}

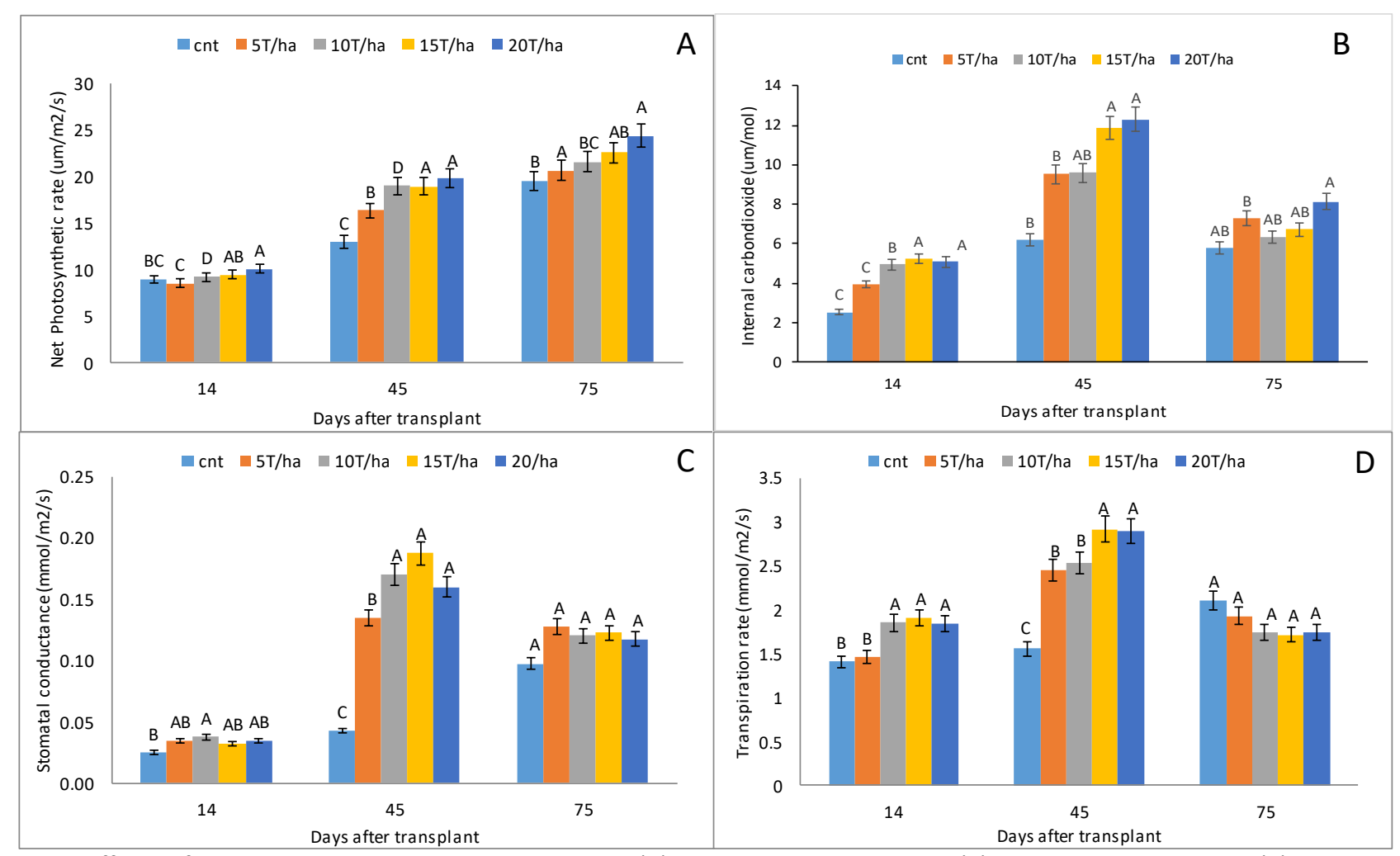

Fig 3. Effects of vermicompost application rates on the (A) Net photosynthetic rate, (B) Internal carbondioxide, (C) Stomatal conductance, (D) Transpiration rate of watermelon. Bars indicate \pm SE and different letters represent the statistical significance at $\mathrm{p}<0.05$

Table 4. Correlation of between physiological and yield parameters of watermelon grown under vermicompost treatment.

\begin{tabular}{|c|c|c|c|c|c|c|c|c|c|c|}
\hline Parameters & $\begin{array}{l}\text { Vine } \\
\text { len. }\end{array}$ & Leaf area & $\begin{array}{c}\text { Net } \\
\text { photos }\end{array}$ & $\begin{array}{l}\text { Stomat } \\
\text { cond. }\end{array}$ & Int. co2 & Transrate & $\begin{array}{l}\text { Days to } \\
50 \% \text { Flw }\end{array}$ & MF & $\mathrm{FF}$ & $\begin{array}{c}\text { Fruit } \\
\text { weight }\end{array}$ \\
\hline Vine length & 1 & & & & & & & & & \\
\hline Leaf area & $0.894^{*}$ & 1 & & & & & & & & \\
\hline Net photosyn. & 0.606 & $0.880^{*}$ & 1 & & & & & & & \\
\hline Stomatal cond. & $0.901^{*}$ & $0.938^{* *}$ & 0.767 & 1 & & & & & & \\
\hline Int. $\mathrm{CO}_{2}$ & 0.707 & $0.948^{* *}$ & $0.947^{* *}$ & $0.829^{*}$ & 1 & & & & & \\
\hline Transpiration rate & 0.695 & $0.934^{*}$ & $0.950^{* *}$ & $0.888^{*}$ & $0.973^{* *}$ & 1 & & & & \\
\hline Days to $50 \%$ Flw & 0.756 & -0.650 & -0.353 & $-0.858^{*}$ & -0.476 & 0.589 & 1 & & & \\
\hline M. flower & 0.589 & $0.886^{*}$ & $0.979^{* *}$ & 0.788 & $0.975^{* *}$ & $0.981^{* *}$ & 0.422 & 1 & & \\
\hline F. flower & 0.445 & 0.795 & $0.969^{* *}$ & 0.655 & $0.934^{*}$ & $0.926^{*}$ & 0.244 & $0.981^{* *}$ & 1 & \\
\hline Fruit weight & 0.718 & $0.952^{* *}$ & $0.955^{* *}$ & $0.876^{*}$ & $0.991^{* *}$ & $0.995^{* *}$ & 0.552 & $0.983^{* *}$ & $0.931^{*}$ & 1 \\
\hline
\end{tabular}

\footnotetext{
${ }^{* *}$ Correlation is significant at the 0.01 level, ${ }^{*}$ Correlation is significant at the $\mathrm{p}<0.05$ level. MF-male flower, FF-female flower.
} 
recorded that the control and $20 \mathrm{t}$ ha- 1 had the highest mean value for the days to $50 \%$ flowering of watermelon (51.23 and 48.15 days respectively). Results indicated that 5 , 10 and 15 t ha- 1 application rates were not significantly different from each other; however the later has significant differences with the former (Table 2).

Fruit weight recorded was converted to a standard of total fruits weight in kilo gram per hectare ( $\mathrm{kg}$ ha-1). Data collected reveals that 15 and $20 \mathrm{t}$ ha- 1 of vermicompost application rates do not vary statistically with the highest fruit weight of 2566 and 2650 (kg ha-1) respectively. The control on the other hand had the least fruit weight $(1200 \mathrm{~kg}$ ha-1) and it varies significantly with all the treatments tested at $p \leqslant 0.05$ (Table 2 ).

\section{Fruit qualities}

Watermelon rind measured showed that vermicompost application rate at $20 \mathrm{tha}-1(1.13 \mathrm{~cm})$ had the thinnest rind followed by $15 \mathrm{t}$ ha-1 $(1.18 \mathrm{~cm})$ which are significantly different from the control $(1.55 \mathrm{~cm})$ with the thickest watermelon rind (Table 3). Results on the total soluble solids from the table 3 presented above indicates that vermicompost application rate at 20 and $15 \mathrm{t}$ ha- 1 had the value of TSS, 11.13 and 10.23 respectively, which varies significantly with the other treatments. Treatments of 10, 15 and $20 \mathrm{t}$ ha-1 vary significantly with the others in watermelon ash content with values of 7.9, 7.93, $6.93 \%$, respectively, the control has the highest amount of ash content (8.65\%) (Table 3). As can be seen from Table 3 the highest juice content was recorded in vermicompost application rate of $20 \mathrm{t}$ ha-1 (95.5\%) followed by 15 and $20 \mathrm{t}$ ha-1 at 94.5 and $94.08 \%$ respectively, the control varies statistically with all the treated crops and has the least juice content (91.13\%). The $\mathrm{pH}$ values measured reveals that the control is significantly different with $5 \mathrm{t}$ ha- 1 and $20 \mathrm{t}$ ha- 1 application rates of vermicomposting, other treatments do not vary statistically with the former (Table 3 ). The amount of anthocyanin content measured reveals that vermicompost at application rate of $20 \mathrm{t}$ ha- 1 had the highest amount of anthocyanin which is significantly different with least control (0.13) and $5 \mathrm{t} / \mathrm{ha}(0.13)$ (Table 3).

\section{Correlation of the physiological properties}

Results from the correlation matrix reveals that vine length is positively correlated to leaf and stomatal conductance (Table 4). Leaf area is significantly correlated to net photosynthesis, transpiration rate and number of male flowers at $p$ level of 0.05 , hence it is highly related with stomatal conductance, internal carbondioxide and fruit weight at $p$ level of 0.05 (Table 4). Results indicates that net photosynthetic rate has significant positive correlation with internal $\mathrm{CO} 2$, transpiration rate, male and female flowers production and fruit weight. It can be observed from the results that stomatal conductance is positively correlated with internal $\mathrm{CO} 2$, transpiration rate and fruit weight, moreso it has significant negative correlation with days to $50 \%$ flowering (Table 4). However, days to $50 \%$ flowering have negative correlations with flowers production and fruit weight. However, male flower significant relates with female flowers production and fruit weight (Table 4).

\section{Discussion}

Vermicompost application rates at 5 and $10 \mathrm{t}$ ha- 1 significantly increases the length of vines of watermelon at early stage of the plant growth cycle, in this stage the higher rate did not performed as anticipated, this might be so because high rates of vermicompost produces high dose of Ca which can cause retard growth of shoots, this observation is in concordance with the findings of Aggelides and Londra (1999), whom reported that decline in growth of tomato with adding vermicompost was probably due to increase in Ca uptake. In the late vegetative stage of the crops life all the application rates performed more way than the control and this might be so because at the that stage a complete mineralization and integrations of the vermicompost has took place. Higher rate of manure improves moisture availability which inturn enhances and release more nutrient elements for increased vine growth (Enujeke, 2013).

Leaf area of watermelon increases as application rates of vermicompost increases, these was so because higher rates of vermicompost improves the soil physical and chemical properties and gives crop optimum conditions for growth and development. This results tallies with the findings of Aliyu (2000), which indicated that higher rates of manure improves soil properties and increases the growth and development of tomato crop. Arancon et al. (2004) reported positive effects of vermicompost in increasing leaf area of tomato, pepper and strawberry plants. Leaf area aslo increased by growth regulators application and phloemic stress (Saifuddin et al., 2009). A higher rate of vermicompost gives higher net photosynthetic rate in watermelon. Nutrients such as $\mathrm{N}, \mathrm{P}, \mathrm{K}, \mathrm{Mg}, \mathrm{Fe}$ and $\mathrm{Cu}$, are abundantly found in vermicompost which are used in the formation of chlorophyll which is required for synthesizing of light and subsequent conversion into chemical energy via photoassimilation (Tanaka et al., 1998). Vermicompost at different application rates enhanced the production of chlorophyll and improves photosynthetic activity in some selected horticultural crops. This improved photosynthesis may increased the carbohydrates availability in the plant parts. Moneruzzaman et al. (2010a) reported that exogenous application of sugar to the plant parts improved the quality of deatached plant parts. Theunissen et al. (2010) and also Ali (2014) reported that increased vermicompost at 30\%, enhances total leaf chlorophyll content of marigold plant. Results from this experiment shows that higher rate of vermicompost enhanced the stomatal conductance of watermelon crops. According to Khandaker et al. (2017), the highest value of stomatal conductivity of chilli was recorded with the application of vermicompost. It was also observed from the results the higher the net photosynthetic rate the higher the stomatal conductance. Stomatal conductance improves the net photosynthetic rate by regulating $\mathrm{CO} 2$ fixation in the leaf mesophyll tissue and is positively correlated with photosynthesis (Khandaker et al., 2013a). Transpiration rates increases as plant growth with increase in vermicompost rate, this was so probably because the increase rate of NPK has effects on internal $\mathrm{CO} 2$, and this findings is in conflict with that of Zhu et al. (2010), who reported that increase in NPK rate reduces the transpiration rate of tomato plant. Berova and Karanatsidis (2009) reported that increase photosynthetic pigments and leaf gas exchange in Capsicum annum due to application of 
vermicompost. At the fruit maturation stage of the crop's life the lesser rate out-performs the higher rates; this might be so because the chlorophyll content and other pigment lost from the leaf mesophyll tissue. Days required to $50 \%$ flowering were enhanced with application of high rates of vermicompost in this current study. Haruna et al. (2011) reported that increasing poultry dung rates significantly increases number of days to $50 \%$ flowering. However, the highest rate of $20 \mathrm{t}$ ha-1 does not vary significantly with the control, this might be so because the high dose of vermicompost may distort the soil microbial and physical properties as the experiment was conducted in a pot. From this study, significant minimum days were recorded for flower formation in pots treated with 5, $1015 \mathrm{t}$ ha-1 of vermicompost. Prasad et al. (2009) similarly reported some results in Momordica charantia and Cucumis sativus. In this research, it was observed that number of flowers increases asymmetrically as vermicompost rates increases geometrically. Marc et al. (2015) reported that increased vermicompost improves the number of flowers. A research conducted by Ali (2014) on Calendula officinalis reveals that the highest number of flower bud and open floret was achieved in $60 \%$ vermicompost treatment. Some other agricultural practices like as removal of young leaves and growth regulators application stimulates the flowering and improve the flower quality (Moneruzzaman et al., 2010b). Increase in flower number has to with increases in photosynthetic activities and carbohydrate accumulation within the plant (Khaderker et al., 2017). The results are in concordance with those of Roychaudhury et al. (1995) who reported that number of fruit per plant increases with increasing nitrogen application and assimilation rate. It was also reported that carbohydrate accumulation is high in the girdle branch which increase the number of fruits (khandaker et al., 2011). Our results showed that numbers of male flowers outweighs that of the opposite sex, this was so because; the male flowers are initially produced in a watermelon crop. This is supported with the findings of Thriveni (2015), who stated that the female flowers of melon initiates 10 days after the production of the male flowers. Similarly, it was also observed that different rate of vermicompost on Chrysanthemum chinensis produces high fresh weight of flowers and number of flowers per plant (Nethra et al., 1999).

Results from the study conducted shows that fruit weight was enhanced as vermicompost application rate was increasing. Increase in vermicompost rate had significant effect on fruit yield and weight this was because the vermicompost improves moisture retention in the soil and improves soil chemical and microbiological activities. This is supported by Edwards and Burrows 1988; Canellas et al. 2002. Application of organic manures increases fresh weights of the fruits per plant (Khandaker et al., 2017). In a similar research conducted by Thriveni (2015), he reported that bitter gourd produces $4000 \mathrm{~kg}$ ha-1 of fruit weight with increased rate of vermicompost. Vermicompost applied at a rate of $5 \mathrm{t}$ ha- 1 have also been reported to significantly increase yield of tomato (5.8 t ha-1) in farmers' fields compared with control ( $3.5 \mathrm{t}$ ha-1) (Nagavallemma et al., 2004). Crop growth regulators and other plant growth influencing substances produced by microorganisms are also present in vermicompost (Tomati et al., 1988), higher rates of VC influences the rind thickness of watermelons, this might in relation of the growth regulators in VC. Fruit juice and total soluble solids content in fruits are impotant parameters that strongly affect consumer acceptability (Moneruzzaman et al., 2011).

It has been reported that growth regulators increased fruit juice, TSS content and produced better quality fruits ( Khandaker et al., 2013b). Moreso, there direct correlation of increasing VC rates with ripening of fruits thus the TSS content, juice content and percentage of ash of watermelon fruits can be attributed higher rates of vermicomposting, this agrees with the findings of Gutrierrez et al. (2007). The $\mathrm{pH}$ value of influences the ability of minerals to dissolve in water, continues increment in VC rates increases the $\mathrm{pH}$ of watermelon fruits. Accumulation of anthocyanin content in fruits varied with the growing condition and growth regulators application (Khandaker et al., 2012). Fruit quality trait like the anthocyanin content was enhanced in this study, and it suffice to suggest that high rates of VC positively influences the anthocyanin content in a watermelon, different rates of vermicompost might have favored the cultivation of firmer, better colored and quality fruit (Singh et al. 2008).

\section{Materials and methods}

\section{Plant materials}

A potted research was conducted at the teaching and research farm of the Faculty of Bioresources and Food Industry at Universiti Sultan Zainal Abidin (UnisZA), Besut Campus, Besut, Terengganu, Malaysia, with atmospheric annual temperature of $21-30^{\circ} \mathrm{C}$ and relative humidity of 60 $90 \%$. Located at $5.7471^{\circ} \mathrm{N}, 102.6101^{\circ} \mathrm{E}$. In this research, watermelon Red Flesh Seedless Variety (Crimson sweet F1 hybrid) was used as planting materials and different application rates of vermicompost was the major factor of the experiment. Application rates of 5, 10, 15, $20 \mathrm{t}$ ha- 1 and untreated control were applied with four replications each, single plant was taken as an experimental unit from each replicate.

\section{Experimental design and treatment application}

The research was a potted layout experiment in a Completely Randomized Design (CRD). Sixteen (16) pots were randomly arranged in a nursery and $10 \mathrm{~kg}$ of soil was added into each pot until $10 \mathrm{~cm}$ of soil furrow slice was achieved. Vermicompost was analyzed before the treatment application (Table 1). Vermicompost application rate was converted from the standard $t$ ha- 1 and applied to the pots in $\mathrm{g} /$ pot, using the following formular: $10,000 \mathrm{~m} 2$ in one hectare $\times 0.1 \mathrm{~m}$ soil depth $\times 1.5 \mathrm{~g} / \mathrm{cm} 3$ bulk density $=1500 \mathrm{t}$ ha-1 of soil.

Furrow slice $=1$ ha has $1500000 \mathrm{~kg}$ of soil.

If $1 \mathrm{t}$ ha- 1 is used for $10 \mathrm{~kg}$ soil (pot soil),

Then, ton is converted into $\mathrm{kg}$,

$=(1000 \mathrm{~kg}$ (VC@ $1 \mathrm{t} / \mathrm{ha})) /(1500000 \mathrm{~kg})=0.00067 / \mathrm{kg}-1$ soil

Convert $\mathrm{kg}$ to $=0.67 \mathrm{~g}$ of $\mathrm{VC} / \mathrm{kg}-1$

$=0.067 \times 10$ (soil in pot)

$=6.7 \mathrm{~g} /$ pot @ $1 \mathrm{t} \mathrm{ha}-1$ 


\section{Measurement of vine length and leaf area}

Vine length was measured from the base of randomly selected five plants/plot to the growing tip of a main vine using a flexible measuring tape as per methods used by Grant and Todd (2001). The main vine was chosen from those beginning close to the base of the plant and extending the farthest from the base, vine length was measured at intervals. Fresh leaves from watermelon branches are randomly collected washed, clean and flattened beforehand from each plot and measured by using the Leaf Area Meter (Model Portable Laser Cl-202, CID Bio-science, USA) with replicate data recorded.

\section{Photosynthetical characteristics}

Data for net photosynthetic rate $(\mathrm{Pn})$ was recorded as $\mu \mathrm{m} / \mathrm{m} 2 / \mathrm{s}$.Transpiration rate (E) data was read as $\mathrm{mmol} / \mathrm{m} 2 / \mathrm{s}$. Stomatal conductance (C) was read as $\mathrm{mmol} / \mathrm{m} 2 / \mathrm{s}$. Finally, internal carbon dioxide concentration (IntCO2) was recorded as $\mu \mathrm{m} / \mathrm{mol}$. Data were collected using same equipment, C1-340 Handheld Photosynthesis System (CID Bio-Science, USA). All the necessary setup and calibaration were followed according to manual of C1-340 Handled Photosynthesis System (CID Bio-Science, USA) given. Photosynthesis rate was determined by measuring the rate at which a known leaf area assimilates the $\mathrm{CO} 2$ concentration in a given time. The calculation for net photosynthetic rate was determined as below:

$\mathrm{Pn}=-\mathrm{W} \times(\mathrm{Co}-\mathrm{Ci})=-2005.39 \times((\mathrm{V} \times \mathrm{P}) /(\mathrm{Ta} \times \mathrm{A})) \times(\mathrm{Co}-\mathrm{Ci})$

Where $\mathrm{Pn}$ : Net photosynthesis rate $(\mu \mathrm{mol} / \mathrm{m} 2 / \mathrm{s}), W$ : mass flow rate, $\mathrm{Co}(\mathrm{Ci})$ : outlet (inlet) $\mathrm{CO} 2$ concentration (ppm or $\mu \mathrm{mol} / \mathrm{mol}), \quad \mathrm{P}$ : atmospheric pressure (bar), Ta: air temperature, A: leaf area $(\mathrm{cm} 2)$.

While, the rate of transpiration was determined by the water vapour flux accumulates per one

sided leaf in a given times. The calculation used to get the transpiration rate as below:

$\mathrm{E}=((\mathrm{eo}-\mathrm{ei}) /(\mathrm{P}-\mathrm{eo})) \times \mathrm{W} \times 103$

eo $=$ hro $\times$ es $/ 100$ ei $=$ hri $\times$ es $/ 100$

es $=6.13753 \times 10-3 \times$ e Ta $\times(18.564-\mathrm{T} / 254.4) /(\mathrm{Ta}+255.57)$

Where eo (ei): outlet (inlet) water vapour (bar), P: atmospheric pressure (bar), es: saturated water vapour at air temperature (bar), Ta: air temperature (oC), hro (hri): outlet (inlet) relative humidity (\%).

\section{Flower production and number of fruits produced}

From the initial planting of the seedlings to the flowering of $50 \%$ of crops on each plot, the number of flowers and buds on crops are recorded and presented as days to $50 \%$ flowering. Male and female flowers are also counted separately and recorded in the log book. Ripe fruits were determine by observing the tendril (dried and brown tendril signifies ripe fruits) or the watermelon fruits were gently hit and metallic or hollow sound is an indication of ripe fruits. Total number of fruits at harvest per treatment were counted and recorded as total yield per hectare.

\section{Determination of fruit qualities}

Fruit rind was measured with the aid of digital vernier calipers and recorded in $\mathrm{cm}$. The total moisture and ash component of the samples were determined by methods describe by Inuwa et al. (2011). Crucibles were oven dried at $900 \mathrm{C}$ for $30 \mathrm{~min}$ and transferred into desiccators to cool. After cooling, watermelon flesh was diced into cubes of 5 $\mathrm{mm} \times 5 \mathrm{~mm} \times 5 \mathrm{~mm}$ size. Each sample was weighed in the crucible and oven dried at $110 \mathrm{oC}$ to a constant weight. The percentage juice and ash content of each sample were then calculated. Total soluble solids was determined with use of handheld refractometer. And juice $\mathrm{pH}$ was measured with using a glass electrode $\mathrm{pH}$ meter after extracting the juice and sieving the pulp. Photometric determination of anthocyanins was performed, spectrometer was used to determine the absorptions of samples. Absorption of the extracts at 530- and 657-nm wavelength was determined photometrically.Quantification of anthocyanins was performed using the following equation: QAnthocyanins $=\left(\right.$ A530 $-0.25^{*}$ A657) $\times \mathrm{M}-1$, where QAnthocyanins is a corrected absorption value linearly correlatedwith the amount of anthocyanins, A530 and A657 is the absorption at the indicated wavelengths and $M$ is the weight of the plant material used for extraction (g).

\section{Statistical analysis}

Data were analyzed for the differences in the mean value among the treatments by using one way repeated ANOVA procedure and means were separated using Duncan's Multiple Range Test (DMRT) with SAS 9.4. Differences at $P$ $\leqslant 0.05$ were considered as significant

\section{Conclusion}

From the results above on the effects of different application rate of vermicompost on red seedless watermelon growth and yield, all the rates are superior to the control but higher rates of 15 and $20 \mathrm{t}$ ha- 1 gave the best result in growth and yield of watermelon. Application of vermicompost at the rate of $15 \mathrm{t}$ ha-1 increased stomatal conductance, transpiration rate and the least days required to $50 \%$ flowering was significantly different compared with other treatments and control. Vermicompost application at the rate of $20 \mathrm{t}$ ha-1 positively influences leaf area, net photosynthetic rate, internal carbon dioxide, number of flowers and fruits weight of watermelon. This findings also reveals that quality properties of watermelon like rind thickeness, TSS, pH, Anthocyanin, Juice and ash contents were improved with the application rate of 15-20 t ha-1. Vermicompost application rate of $15-20 \mathrm{t}$ ha- 1 is recommended for watermelon production.

\section{Acknowledgement}

We greatly thank the Research Management, Innovation \& Commercialization Centre (RMIC), Universiti Sultan Zainal Abidin (UniSZA), Terengganu, Malaysia for giving support in the publication of this research.

\section{References}

Adeoye GO, Sridhar MKC, Adeoluwa OO, Oyekunle M, Makinde EA, Olowoake AA (2007) Comparative evaluation oforganomineral fertilizer and mineral fertilizer on yield and quality of maize. Nigerian J Soil Sci. 18: 132-137. 
Aggelides SM, Londra PA (1999) Effects of compost produced from town wastes and sewage sludge on the physical properties of a loamy and a clay soil. Bioresour Technol. 71: 253-259.

Ali A (2014) Response of sorghum and soil to combined application of NPK with poultry manure and cow dung in Makurdi, southern guinea savanna zone of Nigeria, Res J Agril Environ Manag. 3(9): 485-489.

Aliyu $L(2000)$ The effects of organic and mineral fertilizer on the growth, yield and composition of pepper (Capsicum annum L). Biol Agril Hort. 18:29-36.

Arancon N, Edwards C, Atiyeh R, Metzger J (2004) Effects of vermicomposts produced from food waste on the growth and yields of greenhouse peppers. Bioresour Technol. 93(2): 139-144.

Berova M, Karanatsdis G (2009) Influence of bio-fertilizer, produced by Lumbricus rubellus on growth, leaf gas exchange and photosynthetic content of pepper plants (Capsicum annuum L.). Acta Hort. 830: 447-452.

Boyhan GE, Granberry DM, Kelley WT (2000) Commercial watermelon production. University of Georgia, Cooperative Extension Service, Bulletin 996, 1-32.

Enujeke EC (2013) An assessment of some growth and yield indices of six varieties of watermelon (Citrulus Lanatus Thumb) in Asaba area of Delta State, Nigeria. Int Res J Agril Sci Soil Sci. 3(11):376-382.

Grant P, Todd C (2001) Vine length of a diverse set of watermelon cultivars. Department of Horticultural Science, North Carolina State University, Raleigh, NC 27695-7609. Cucurbit Genetics Cooperative Rep. 24:65-67

Gutierrez-Miceli FA, Santiago-Borraz J, Montes Molina JA, Nafate CC, Abud-Archila M, Oliva Llaven MA, Dendooven L (2007) Vermicompost as a soil supplement to improve growth, yield and fruit quality of tomato (Lycopersicon esculentum). Bioresour Technol 98:2781-2786.

Haruna IM, Aliyu L, Olufajo OO, Odion EC (2011) Growth of Sesame ( Sesamum indicum L .) as Influenced by Poultry Manure, Nitrogen and Phosphorus in Samaru, Nigeria, 10(4):561-568.

IITA (2013) Growing watermelon commercially in Nigeria- an illustrated guide. Int Ins Trop Agril. 1-16.

Inuwa HM, Aina VO, Gabi B, Aimola I, Thompson V (2011) Determination of differences in nutrient composition of Citrullus vulgaries (water melon) fruits after plucking. British J Dairy Sci. 2: 27-30.

Jeffries P (1987) Use of mycorrhizae in agriculture. Crit Rev Biotech. 5: 319- 348.

Khandaker MM, Dalorima T, Hailmi M, Mat N (2017) Effect of different rates of inorganic fertilizer on physiology, growth and yield of okra (Abelmoschus esculentus) cultivated on BRIS soil of Terengganu, Malaysia. Aust J Crop Sci. 11(07):880-887.

Khandaker MM, Boyce AN, Normaniza O, Faruq G, Rahman MM, Sofian-Azirun M (2013a) The influence of 1triacontanol on the growth, flowering, and quality of potted Bougainvillea plants (Bougainvillea glabra var. "elizabeth angus") under natural conditions. Sci World J. 2013:1-13.

Khandaker KM, Boyce AN, Normaniza O, Faruq G, Motior Rahman M, Sofian-Azirun M (2013b) Fruit development, pigmentation and biochemical properties of wax apple as affected by localized application of GA3. Braz Arc Biol Technol. 56(1):11-20.
Khandaker MM, Boyce AN, Normaniza O, Hossain ABMS (2012) Physiochemical and phytochemical properties of wax apple (Syzygium samarangense [Blume] Merrill \& L.M. Perry) as affected by growth regulator application under field conditions. Sci World J. 2012: 1-13

Khandaker KM, Hossain ABMS, Osman N, Boyce AN (2011) Application of girdling for improved fruit retention, yield and fruit quality in Syzygium samaragense under field conditions. Int J Agril Biol. 13(1):18-24.

King LD (1990) Soil nutrient management in the United States. In sustainable Agricultural system, Ed. C.A. Edwards et al., St. Lucie Press. FL., Pp: 89-106.

Leonard SW, Lin DS, Lederer C, Traber MG, Zhao Y (2006) Retention of fortified vitamin $E$ and sensory quality of fresh-cut pears by vacuum impregnation with honey. J Food Sci. 71(7):S553-S559.Li D, Hockaday WC, Masiello CA, Alvarez PJJ (1991) Earthworm avoidance of biochar can be mitigated by wetting. Soil Biol Biochem. 43:1732-1737.

Marc ZA, Walters SA, Brian SC, Masabni JG (2015) Effect of soil type and vermicompost applications on tomato growth. Int J Recycl Organic Waste Agril. 135-141.

Moneruzzaman KM, Hossain ABMS, Amru NB, Saifudin M, Imdadul $\mathrm{H}$ and Wirakarnain S (2010a) Effect of sucrose and kinetin on the quality and vase life of Bougainvillea glabra var. Elizabeth Angus bracts at different temperatures. Aust J Crop Sci. 4(7):474-479.

Moneruzzaman KM, Hossain ABMS, Normaniza O, Saifudin M, Sani W, Amru NB (2010b) Effects of removal of young leaves and cytokinin on inflorescence development and bract enlargement in Bougainvillea glabra var. "Elizabeth Angus". Aust J Crop Sci. 4 (7): 467-473.

Moneruzzaman KM, Al-Saif AM, Alebedi Al, Hossain ABMS, Normaniza O, Nasrulhaq Boyce A (2011) Nutritional quality evaluation of three cultivars of Syzygium samaragense under Malaysian conditions. Afr J Agril Res. 6 (3):545-552.

Nagavallemma KP, Wani SP, Lacroix S, Padmaja VV, Vineela C, Babu RM, Sahrawat KL (2004) Vermicomposting: Recycling wastes into valuable organic fertilizer. Global Theme on Agrecosystems Report no. 8. Patancheru 502 324, Andhra Pradesh, India.

Nethra NN, Jayaprasad KV, Kale RD (1999) China aster (Callistephus chinensis (L.) Ness) cultivation using vermicomposts as organic amendment. Crop Res Hisar. 17: 209-215.

Odedina JN, Odedina SA, Ojeniyi SO (2011) Effect of types of manure on growth and yield of cassava (Manihot esculenta, Crantz). Researcher. 3(5): 1-8.

Prasad PH, Mandal AR, Sarkar A, Thapa U, Maity TK (2009) Effect of biofertilizers and nitrogen on growth and yield attributes of bitter gourd (Momordica charantia L). Proc Int Con Hort 2009. Pp. 738-739.

Roychaudhury AR, Chatterjee S, Mitra K (1995) Effect of different doses of nitrogen, phosphorus, potassium, magnesium, calcium and iron on growth and developmentin chilli. Department of Horticulture Kalyani West Bengal India; 13: 96-99

Saifuddin M, Sharif Hossain ABM, Normaniza O, Moneruzzaman KM (2009) Bract size enlargement and longevity of Bougainvillea spectabilis as affected by GA3 and phloemic stress. Asian J Plant Sci. 8(3): 212-217. 
Singh R, Sharma RR, Kumar S, Gupta RK, Patil RT (2008) Vermicompost substitution influences growth, physiological disorders, fruit yield and quality of strawberry (Fragaria 9 ananassa Duch.). Bioresour Technol. 99:8507-8511.

Stancheva I, Mitova I, Petkova Z (2004) Effects of different nitrogen fertilizer sources on the yield, nitrate content and other physiological parameters in garden beans. J Exp Bot. 52:277- 282.

Tanaka T, Wimol S, Mizutani T (1995) Inheritance of fruit shape and seed size of watermelon. J Japan Soc Hort Sci. 64(3): 543-548.

Tarafdar JC, Marschner H (1994) Phosphatase activity in the rhizosphere and hyphosphere of VA mycorrhizal wheat supplied with inorganic and organic phosphorus. Soil Biol Biochem. 26(3). 387-395.
Theunissen J, Ndakidemi PA, Laubscher CP (2010) Potential of vermicompost produced from plant waste on the growth and nutrient status in vegetable production. Int J Phy Sci. 5(13): 1964-1973.

Thriveni V, Mishra HN, Pattanayak SK, Sahoo GS, Thomson T (2015) Effect of inorganic, organic fertilizers and biofertilizers on growth, flowering, yield and quality attributes of bitter gourd, Momordica charantia L. Int J Farm Sci. 5(1), 24-29.

Zhu J, Liang Y, Zhu Y, Wanglin H, Lin X, Xing Wu Luo A (2010) The interactive effects of water and fertilizer on photosynthetic capacity and yield in tomato plants. Aust J Crop Sci. 6(2):200-209. 